\title{
RETROSPECTIVE EVALUATION THE CONCORDANCE OF IMAGING MODALITIES IN PATIENTS ADMITTED TO THE EMERGENCY DEPARTMENT WITH ABDOMINAL PAIN
}

\author{
Acil Servise Karın Ağrısı Nedeniyle Başvuran Hastaların Görüntüleme Yöntemleri Uyumunun \\ Retrospektif Olarak Değerlendirilmesi
}
Cihat AYGÜN¹, Emine EMEKTAR ${ }^{1}$, Şeref Kerem ÇORBACIOĞLU'1, Hüseyin UZUNOSMANOĞLU ${ }^{1}$, Yunsur CEVİK ${ }^{1}$

${ }^{1}$ Keçiören Training and Research Hospital, Department of Emergency Medicine, ANKARA

Introduction: In the present study, we aimed to evaluate concordance of imaging modalities of patients admitted to the emergency department (ED) with abdominal pain.

Material and Methods: The study was conducted between the dates 01.06.2014-31.05.2015 after the local ethical committee approval. Patients admitted to the ED, with abdominal pain, whose multiple imaging were done (abdominal ultrasonography; USG and computed tomography; CT) were screened for 1 year retrospectively. Data analysis was performed using SPSS 15.0.

Results: The study included a total of 413 patients of which 242 $(58.6 \%)$ of women. The final diagnosis of the patients, 133 $(32.2 \%)$ patients had nonspecific abdominal pain, the most commonly seen surgical diagnosis was acute appendicitis. When the sensitivities of USG and CT evaluated regarding the final diagnosis it was $38.9 \%$ and $86.1 \%$, respectively for acute appendicitis, $0 \%$ and $30.4 \%$ respectively for acute pancreatitis, $65.4 \%$ and $98.1 \%$ respectively for ovarian pathology, $94.9 \%$ and $87.2 \%$ respectively for acute cholecystitis. There was detected concordance in $63.2 \%$ between USG and CT. While this rate was $61.7 \%$ among recent diagnosis with USG, for CT recent diagnoses it was found as $87.7 \%$.

Conclusion: In conclusion, when final diagnoses are compared with imaging methods in patients with abdominal pain, CT seems superior to USG. Especially in clinics where USG cannot be performed for 24 hours like in our clinic, CT may be preferred as the first imaging method.

Giriş: Çalışmamızda, acil servise karın ağrısı nedeniyle başvuran hastaların görüntüleme yöntemleri uyumunun değerlendirilmesi amaçlanmıştır.

Gereç ve Yöntem: Çalışma lokal etik kurul onayı alındıktan sonra 01.06.2014-31.05.2015 tarihleri arasında retrospektif olarak yapıldı. Acil Tıp Kliniğine karın ağrısı nedeniyle başvuran, birden fazla görüntüleme yöntemi (Batın ultrasonografisi; USG) ve Bilgisayarlı tomografisi; BT) yapılmış hastalar 1 yıl geriye yönelik tarandı. Verilerin analizi SPSS 15.0 kullanılarak yapıldı.

Bulgular: Çalışmaya 242 (\%58.6)'si kadın toplam 413 hasta dâhil edildi. Son tanılara bakıldığında, 133 (\%32.2) hastanın son tanısı nonspesifik karın ağrısı, en sık görülen cerrahi tanı ise akut apandisit oldu. Son tanılara göre USG ve BT'nin duyarlılıkları değerlendirildiğinde, akut apandisit için USG $\% 38.9$, BT \%86.1, akut pankreatit için USG \%0, BT \%30.4, over patolojisi için USG \%65.4 BT \%98.1, akut kolesistit için USG \%94.9 BT \%87.2 duyarlı bulundu. USG ile BT arasında $\% 63.2$ tan1 uyumu saptand1. Bu oran USG ile son tanılar arasında \%61.7 iken BT ile son tanılar arasında \%87.7 olarak bulundu.

Sonuç: Sonuç olarak çalışmamızda karın ağrılı hastalarda görüntüleme yöntemleri son tanılarla karşılaştırıldığında BT, USG'ye kıyasla, daha üstün görünmektedir. Özellikle bizim kliniğimiz gibi 24 saat USG yapılamayan kliniklerde BT ilk görüntüleme yöntemi olarak tercih edilebilir.
\end{abstract}

Keywords: Abdominal pain, computed tomography, emergency department, ultrasonography
Anahtar Kelimeler: Karın ă̆rısl, bilgisayarl tomografi, acil servis, ultrasonografi 


\section{INTRODUCTION}

Emergency Departments (ED) are units where health services are delivered to patients in an uninterrupted manner. Abdominal pain is a common cause to apply the ED and constitutes 5-8\% of all ED applications (1). Acute abdominal pain is a non-traumatic evolving symptom that occurs during the course of disease of abdominal organs or organs outside the abdomen which lasts less than a week. Acute abdominal pain may be a sign of a medical or surgical emergency (2). Among the causes of application to ED's abdominal pain takes 6th place and the 4th most common cause of all medical emergencies (2).

Approach to patients with abdominal pain, although the history and physical examination is essential, abdominal pain is difficult to interpret clinically and laboratory results are often nonspecific. For verification of the diagnosis and treatment planning, imaging methods and relevant field consultations are needed. Radiography, ultrasonography (USG) and computed tomography (CT) are imaging methods which are often used in ED. Diagnosis and treatment of acute abdominal pain in the ED, despite all the technological advances, is still one of the important clinical problems.

This study aims to evaluate concordance of imaging modalities of patients admitted to the ED with abdominal pain.

\section{MATERIALS AND METHODS}

The study was conducted retrospectively between the dates 01.06.2014-31.05.2015 after the local Ethical Committee approval (Kecioren Training and Research Hospital Ethical Committee 14.10.2015/914). Patients admitted to the ED, with abdominal pain, whose multiple imaging were made (abdominal USG and CT) were screened for 1 year retrospectively. Age, gender, demographics, physical examination, vital signs, laboratory tests, imaging methods and results, requested consultations, duration of stay in the ED with the latest diagnostic and surgical procedures as well as the results were recorded in the study forms. In addition, concordance of diagnostic with imaging results and results of imaging methods, and final diagnoses of the patients were investigated.

Surgery and pathology diagnoses were considered for the patients included in the study with a final diagnosis of undergoing surgery. Non-surgery patients were called 1 week later and control imaging results, consultation diagnosis, and service admission diagnoses were obtained from information processing unit of hospital. The final diagnosis was determined by laboratory findings for hospitalized patients.

\section{Inclusion criteria}

- Patients admitted to the ED with short-term abdominal pain less than one week

- Patients with abdominal CT and abdominal USG applied

- Patient with 18 age and older

\section{Exclusion criteria}

- Patients whose information can not be reached

- Trauma Patients

- Patients with abdominal pain lasting more than 1 week

- Patients without abdominal CT or abdominal USG imaging

- Patients younger than 18 years of age

- Pregnant women

- Statistical analysis

Data analysis was performed by using SPSS software (version 15, Inc., Chicago, USA). The Shapiro-Wilk test was used to assess the normal distribution of the variables. Descriptive statistics were shown as mean \pm standard deviation or median (minimum-maximum), categorical variables were shown with the number of cases as (n) and (\%). Categorical variables were assessed using Pearson's chi-square test. $p$ value less than 0.05 was considered as statistically significant. 


\section{RESULTS}

The study included a total of 413 patients of which 242 $(58.6 \%)$ of women. The mean age of the patients was found as 40. Most requested consultation was general surgery with $315(76.3 \%)$ consultations. When evaluated the final diagnoses of the patients, the most common diagnosis was nonspecific abdominal pain, the most common surgical diagnosis was acute appendicitis. The demographic characteristics of the patients are shown in Table 1.

Table 1: Demographic characteristics of patients

\begin{tabular}{|c|c|}
\hline \multicolumn{2}{|l|}{$\operatorname{Sex}(\mathrm{n} \%)$} \\
\hline Female & $242(58.6 \%)$ \\
\hline Male & $171(41.4 \%)$ \\
\hline Age [median (minimum-maximum )] (Year) & $40(18-100)$ \\
\hline Duration of stay in emergency service [median (minimum-maximum)] (hour) & $10(3-70)$ \\
\hline \multicolumn{2}{|l|}{ Vital Findings [median (minimum-maximum)] } \\
\hline Systolic Blood Pressure (mmHg) & $127(70-170)$ \\
\hline Diastolic Blood Pressure (mmHg) & $80(40-110)$ \\
\hline Temperature $\left(\mathrm{C}^{\circ}\right)$ & $36.6(35.4-38.9)$ \\
\hline \multicolumn{2}{|l|}{ Final diagnosis of patients } \\
\hline Nonspecific abdominal pain & $133(32,2 \%)$ \\
\hline Acute appendicitis & $72(17.4 \%)$ \\
\hline Over pathology & $52(12.6 \%)$ \\
\hline Acute cholecystitis & $39(9.4 \%)$ \\
\hline Renal pathology & $20(4.8 \%)$ \\
\hline Mesenteric lymphadenopathy & $32(7.7 \%)$ \\
\hline Acute pancreatitis & $23(5.6 \%)$ \\
\hline Intestinal obstruction & $13(3.1 \%)$ \\
\hline Other pathologies & $29(7 \%)$ \\
\hline \multicolumn{2}{|l|}{ Consultations requested from patients [n (\%)] } \\
\hline General Surgery & $315(76.3 \%)$ \\
\hline Gynecology & $103(24.9 \%)$ \\
\hline Gastroenterology & $65(15.7 \%)$ \\
\hline Urology & $16(3.9 \%)$ \\
\hline Internal medicine & $14(3.4 \%)$ \\
\hline \multicolumn{2}{|l|}{ BT Types [n (\%)] } \\
\hline Enhanced contrast & $390(94.4 \%)$ \\
\hline Unenhanced contrast & $23(5.6 \%)$ \\
\hline \multicolumn{2}{|l|}{ Emergency Outcome of Patients [n (\%)] } \\
\hline Discharge & $206(49.9 \%)$ \\
\hline Surgery & $105(25.4 \%)$ \\
\hline Hospitalization of Service & $100(24.2 \%)$ \\
\hline Exitus & $2(0.5 \%)$ \\
\hline
\end{tabular}

CT: Computerized tomography 
When USG and CT scan results of the patients are evaluated, pathology has been most reported acute appendicitis $(12.1 \%$ and $17.9 \%$, respectively) (Table 2). In our study, 105 (25.4\%) surgical operations were applied. Operation diagnoses are shown in Table 3. According to the latest diagnostic USG and CT sensitivity was evaluated: it was $38.9 \%$ and $86.1 \%$, respectively for acute appendicitis, $0 \%$ and $30.4 \%$ respectively for acute pancreatitis, $65.4 \%$ and $98.1 \%$ respectively for ovarian pathology, $94.9 \%$ and $87.2 \%$ respectively for acute cholecystitis.

The compliance rate was $63.2 \%$ for USG and CT. CT recent diagnoses for CT was $87.7 \%$ while it was $61.7 \%$ for USG recent diagnosis, the compliance of final diagnoses of the patient table with diagnostic USG and CT diagnosis are shown in Table 4.

Table 2: Distribution of USG and CT diagnosis according to final diagnosis of patients

\begin{tabular}{lccccc}
\hline Final Diagnosis & \multicolumn{2}{c}{ USG } & \multicolumn{2}{c}{ CT } & \multicolumn{1}{c}{$\mathrm{p}$} \\
\cline { 2 - 5 } & $\mathrm{n}$ & $\%$ & $\mathrm{n}$ & $\%$ & 0.711 \\
Normal & 115 & 86.5 & 122 & 91.7 & 0.004 \\
Acute Appendicitis & 39 & 54.2 & 8 & 11.1 & 0.007 \\
Acute Pancreatitis & 14 & 60.9 & 9 & 39.1 & 0.424 \\
Over Pathology & 13 & 25 & 1 & 1.9 & 0.111 \\
Acute Cholecystitis & 2 & 5.1 & 5 & 12.8 & 0.126 \\
Mesenteric Lymphadenopathy & 17 & 53.1 & 2 & 6.3 &
\end{tabular}

USG: Ultrasonography CT: Computerized tomography

Table 3: Surgical diagnosis of patients

\begin{tabular}{lcc}
\hline Surgical Diagnosis & $\mathrm{n}$ & $\%$ \\
Normal & 3 & 2.9 \\
Acute appendicitis & 72 & 68.6 \\
Over Pathology & 7 & 6.7 \\
Acute cholecystitis & 7 & 6.7 \\
Acute pancreatitis & 2 & 1.9 \\
Intestinal Obstruction & 5 & 4.8 \\
Intestinal Perforation & 3 & 2.9 \\
Other & 6 & 5.7 \\
\hline Total & 105 & 100 \\
\hline
\end{tabular}

Table 4: Concordance of final diagnosis of patients with USG and CT Diagnosis

\begin{tabular}{lcccccc}
\hline & \multicolumn{2}{c}{$\begin{array}{c}\text { USG-CT } \\
\text { Concordance }\end{array}$} & \multicolumn{2}{c}{$\begin{array}{c}\text { Final Diagnosis-CT } \\
\text { Concordance }\end{array}$} & \multicolumn{2}{c}{$\begin{array}{c}\text { Final Diagnosis-USG } \\
\text { Concordance }\end{array}$} \\
\cline { 2 - 7 } & $\mathrm{n}$ & $\%$ & $\mathrm{n}$ & $\%$ & $\mathrm{n}$ & $\%$ \\
Concordance & 261 & 63.2 & 362 & 87.7 & 255 & 61.7 \\
Discordance & 152 & 36.8 & 51 & 12.3 & 158 & 38.3 \\
Total & 413 & 100 & 413 & 100 & 413 & 100 \\
\hline
\end{tabular}

USG: Ultrasonography BT: Computerized tomography 


\section{DISCUSSION}

In this study where we compare the imaging of patients admitted to the emergency department because of abdominal pain to patient results, the recent diagnosis with USG and CT was consistent in $61.7 \% 87.7 \%$ of patients, respectively. CT results have a higher rate of compliance with the final diagnosis in comparison with USG in patients who applied to acute abdominal clinic. Acute abdomen is a condition that should be evaluated together with clinical, physical examination and laboratory findings of the patient, consultation and imaging methods. USG and CT are used after clinics and laboratory tests to support diagnosis and to make differential diagnosis (3). The combination of the two methods improves the diagnostic accuracy (4).

USG, when compared to CT, is a noninvasive, fast, accessible and is relatively cheaper imaging. CT is often used in the evaluation of patients with acute abdominal pain with high diagnostic accuracy. As there are many diseases that can cause acute abdominal disease, in the failure of validation of suspected prediagnosis, to suggest an alternative diagnosis is an important advantage of CT. Rosen et al, in their study involving 536 patients, reported that $\mathrm{CT}$ reduced the rate of hospitalization from the $\mathrm{ED}$ by $17 \%$. It also prevented unnecessary surgery in $62 \%$ of patients and in $13 \%$ surgical treatment was applied earlier (5). Rao et al suggested that CT reduced the duration of hospitalization and avoid unnecessary appendectomy and therefore reducing treatment costs (6).

In this study, surgery and pathology diagnosis in patients undergoing surgical diagnosis were accepted as final diagnosis. For other patient groups, clinical, laboratory, imaging findings and consultation of related consultation as a result of hospitalization notes leaded to final diagnosis. Accordingly, in this study, in 133 of 413 patients $(32.2 \%)$ patients, no pathology was identified and they were discharged with nonspecific abdominal pain. These 115 of these 133 patients, $(86.5 \%)$ USG was reported as normal. When the final $\mathrm{CT}$ results of the patients with nonspecific abdominal pain were observed, $122(91.7 \%)$ have been reported with normal CT. When surgical diagnosis was evaluated, $17.4 \%$ of all patients with acute appendicitis that we have included in our study, also in patients who underwent emergency surgery by $68.6 \%$ is the most common emergency surgical disease. As USG depends on the reliability of the performer in the diagnosis of appendicitis, its reliability ranges between $71-97 \%$, the reliability of $\mathrm{CT}$ in the diagnosis of appendicitis is between $93-98 \%$ (7). However, our study findings are particularly did not coincide with the data for USG. In the study, we found that lower USG diagnostic rates compared to literature. Among the reasons is that our study is a retrospective study, do it may cause data loss. Secondly, our hospital performs USG only during certain time intervals. This may have an impact on our study results. Another reason may be due to the lack of communication in reporting the pre-diagnosis of patients between department of radiology and ED.

Excessive use of CT may cause loss of productivity, increased costs, contrast agent-induced complications and may cause an increase in radiation exposure. When too little used, it may lead to delay in diagnosis with increased morbidity and mortality (8). In the studies conducted accurate clinical information given before CT, it was seen that sensitivity and diagnostic accuracy rate would be increased (9).

In our study, we found that in $61.7 \%$ of patients, the USG diagnosis was concordance with the final diagnosis. In a study conducted by Nuran et al, have evaluated USG in diagnosis and treatment in patients with non-traumatic acute abdomen pain; they found that the first ultrasound diagnosis was concordance with the final diagnosis of $79.3 \%$ patients (10). In the study conducted by Siegel et al, this rate was $80.9 \%$ 
(11). USG concordance is low when we compare it with the literature and this case in addition to the reasons mentioned above, the effects such as intense intestinal gas, obesity, failure to comply with fasting criteria and pain or patient mismatch which are related to the patient, as well as other factors such as trying to be complete the examination of ultrasound in emergency conditions in a shorter period. When CT concordance is assessed final diagnosis was consistent with $87.7 \%$ of patients diagnosed with CT. In the study conducted by Tsushima $\mathrm{Y}$ et al, that have found CT diagnosis compatible with the clinical final diagnosis of in $92.8 \%$ of patients (12). Our CT concordance was similar to the literature. We found CT results in patients presenting with abdominal pain in a higher rate of compliance with the final diagnosis in comparison with USG. Our findings were similar to the literature studies. In the study of Salem $60 \%$ of patients that CT examinations confirmed USG findings but did not give additional information, in 33\% CT results not only confirmed the USG findings but at the same time gave additional information (13).

Our study is a single centered retrospective study. The small number of cases is also one of the limitations of our study. In our hospital, USG is made only during certain periods of time; USG can not be done in the evenings and weekends. Patients could not be taken in the study in this period. This may have an impact on our study results. There is also the possibility of incomplete or incorrect data available in our records in our retrospective study. In our study, radiation exposure, allergic contrast agents nephropathy, reactions due to CT could not be evaluated.

It is presented with a large number of patients with abdominal pain in the ED, which will be determined as acute abdominal pain and to reveal whether abdominal pain requiring emergency surgery, to make differential diagnosis is difficult, despite the use of many laboratory and imaging methods. In conclusion, in our study, when imaging methods are compared with a final diagnosis of patients with abdominal pain, CT seems superior to USG. Especially in clinics where USG cannot be performed for 24 hours like in our clinic, CT may be preferred as the first imaging method. However, contrast agent-induced complications and radiation exposure should be considered.

Funding; none.

Conflict of interest; The authors declare that they have no conflict of interest.

\section{REFERENCES}

1. Cartwright SL, Knudson MP. Evaluation of acute abdominal pain in adults. Am Family Physician. 2008; 77: 971-8.

2. Graff LG, Robinson D. Abdominal pain and emergency department evaluation. Emerg Med Clin North Am. 2001; 19: 123-36.

3. Kıyak G, Korukluoğlu B, Özgün Y, Devay AÖ, Kuşdemir A. Apandisit tanısında Ohmann ve Eskelinen skorları ile lökosit sayısı ve ultrasonografi bulgularının değerlendirilmesi. Ulus Travma Acil Cerrahi Derg. 2009; 15: 77-81.

4. Sala E, Watson CJ, Beadsmoore C, Groot-Wassink T, Fanshawe TR, Smith JC. A randomized, controlled trial of routine early abdominal computed tomography in patients presenting with nonspecific acute abdominal pain. Clin Radiol. 2007; 62: 961-9.

5. Rosen MP, Siewert B, Sands DZ, Bromberg R, Edlow J, Raptopoulos V. Value of abdominal CT in the emergency department for patients with abdominal pain. Eur Radiol. 2003; 13: 418-24.

6. Rao PM, Rhea JT, Novelline RA, Mostafavi AA, McCabe CJ. Effect of computed tomography of the appendix on treatment of patients and use of hospital resources. N Engl J Med. 1998; 338: 1416. 
7. Eryılmaz R, Baş G, Alimoğlu O, Ercan M, Şahin M. Akut apandisit şüpheli hastalarda ultrasonografinin ayırıcı tanıda artan önemi. Ulus Travma Acil Cerrahi Derg. 2001; 17: 28-33.

8. Laméris W, van Randen A, Dijkgraaf MG, Bossuyt PM, Stoker J, Boermeester MA. Optimization of diagnostic imaging use in patients with acute abdominal pain (OPTIMA): Design and rationale. BMC Emerg Med. 2007; 7: 9.

9. Mullins ME, Lev MH, Schellingerhout D, Koroshetz WJ, Gonzalez RG. Influence of availability of clinical history on detection of early stroke using unenhanced CT and diffusionweighted MR imaging. AJR Am J Roentgenol. 2002; 179: 223-8.

10. Nuran MS, Ceyhan M, Baydin A, Genç S, Bayrak IK, Elmali M. The role of ultrasonography in the diagnosis and management of non-traumatic acute abdominal pain. Intern Emerg Med. 2008; 3: 34954

11. Siegel Y, Grubstein A, Postnikov V. Ultrasonography in patients without trauma in the emergency department: impact on discharge diagnosis. J Ultrasound Med. 2005; 24: 1371-6

12. Tsushima Y, Yamada S, Aoki J, Motojima T, Endo K. Effect of contrast-enhanced computed tomography on diagnosis and management of acute abdomen in adults. Clin Radiol. 2002; 57: 507-13.

13. Salem TA, Molloy RG, O'Dwyer PJ. Prospective study on the role of the CT scan in patients with an acute abdomen. Colorectal Dis. 2005; 7:460-6. 